\title{
Receptor for Advanced Glycation End Product-Dependent Activation of p38 Mitogen-Activated Protein Kinase Contributes to Amyloid- $\beta$-Mediated Cortical Synaptic Dysfunction
}

\author{
Nicola Origlia, ${ }^{1}$ Massimo Righi, ${ }^{2}$ Simona Capsoni, ${ }^{3}$ Antonino Cattaneo, ${ }^{4}$ Fang Fang, ${ }^{5}$ David M. Stern, ${ }^{7}$ John Xi Chen, ${ }^{8}$ \\ Ann Marie Schmidt, ${ }^{5}$ Ottavio Arancio, ${ }^{6}$ Shi Du Yan, ${ }^{5,6}$ and Luciano Domenici ${ }^{1,9}$ \\ ${ }^{1}$ Institute of Neuroscience (CNR), Pisa 56100, Italy, ${ }^{2}$ International School for Advanced Studies (SISSA), Trieste 34014, Italy, ${ }^{3}$ Lay Line Genomics, Rome \\ 00128, Italy, ${ }^{4}$ European Brain Research Institute, Rome 00143, Italy, ${ }^{5}$ Department of Surgery and ${ }^{6}$ Department of Pathology and Taub Institute, Columbia \\ University, New York, New York 10032, ${ }^{7}$ Dean's Office, University of Cincinnati, Cincinnati, Ohio 45267, ${ }^{8}$ Harvey Cushing Institutes of Neuroscience, North \\ Shore-Long Island Jewish Health System, New York, New York 11021, and 'Department STB, University of L’Aquila, L'Aquila 67010, Italy
}

Soluble amyloid- $\beta(\mathrm{A} \beta)$ peptide is likely to play a key role during early stages of Alzheimer's disease (AD) by perturbing synaptic function and cognitive processes. Receptor for advanced glycation end products (RAGE) has been identified as a receptor involved in $A \beta$-induced neuronal dysfunction. We investigated the role of neuronal RAGE in A $\beta$-induced synaptic dysfunction in the entorhinal cortex, an area of the brain important in memory processes that is affected early in AD. We found that soluble oligomeric $\mathrm{A} \beta$ peptide (A $\beta 42)$ blocked long-term potentiation (LTP), but did not affect long-term depression, paired-pulse facilitation, or basal synaptic transmission. In contrast, A $\beta$ did not inhibit LTP in slices from RAGE-null mutant mice or in slices from wild-type mice treated with anti-RAGE IgG. Similarly, transgenic mice expressing a dominant-negative form of RAGE targeted to neurons showed normal LTP in the presence of A $\beta$, suggesting that neuronal RAGE functions as a signal transducer for A $\beta$-mediated LTP impairment. To investigate intracellular pathway transducing RAGE activation by $\mathrm{A} \beta$, we used inhibitors of stress activated kinases. We found that inhibiting p38 mitogen-activated protein kinase (p38 MAPK), but not blocking c-Jun N-terminal kinase activation, was capable of maintaining LTP in A $\beta$-treated slices. Moreover, A $\beta$-mediated enhancement of p38 MAPK phosphorylation in cortical neurons was reduced by blocking antibodies to RAGE. Together, our results indicate that A $\beta$ impairs LTP in the entorhinal cortex through neuronal RAGE-mediated activation of $\mathrm{p} 38 \mathrm{MAPK}$.

Key words: amyloid- $\beta$ protein; LTP; RAGE; p38 MAPK; entorhinal cortex; Alzheimer's disease

\section{Introduction}

Overproduction and accumulation of amyloid- $\beta(\mathrm{A} \beta)$ is a pathologic feature of Alzheimer's disease (AD). $A \beta$, particularly $A \beta 42$, has been ascribed a crucial role in neuronal stress (Eisenhauer et al., 2000; Johnson et al., 2002). Studies in AD animal models have highlighted a dichotomy between behavioral deficits and neuropathologic findings. Impaired memory and synaptic loss occur before extensive deposition of amyloid in the brains of AD-type murine models and AD patients (D'Hooge et al., 1996; Hsia et al., 1999; Li et al., 1999; Chapman et al., 1999; Larson et al., 1999; Giacchino et al., 2000; Wirths et al., 2001; Oddo et al., 2003; Ingelsson et al., 2004). These observations suggest that early in

Received June 15, 2007; revised Feb. 19, 2008; accepted Feb. 22, 2008.

This work was supported by National Institutes of Health Grant P01AG17490 and the Alzheimer's Association (S.D.Y.), and Fondazione Cassa di Risparmio di Pisa (05/140) and Italian Ministero Università e Ricerca (PRIN, 2006) (L.D.). S.D.Y. is a co-senior author. We thank Giulio Cappagli and Carlo Orsini for their technical help and assistance. Correspondence should be addressed to either of the following: Luciano Domenici, Institute of Neuroscience (CNR), Via G. Moruzzi 1, 56100, Pisa, Italy, E-mail: domenici@in.cnr.it; or Shi Du Yan, Department of Pathology and Surgery, Taub Institute Columbia University, New York, NY 10032, E-mail: sdy1@columbia.edu. DOI:10.1523/JNEUROSCI.0204-08.2008

Copyright $\odot 2008$ Society for Neuroscience $\quad$ 0270-6474/08/283521-10\$15.00/0
$\mathrm{AD}$, when levels of $\mathrm{A} \beta$ are low, mechanisms amplifying and focusing the effects of $A \beta$ on cellular targets contribute to neuronal dysfunction.

Previous studies showed that $\mathrm{A} \beta$ affects synaptic plasticity in the hippocampus (for a review, see Selkoe, 2002). In particular, oligomeric A $\beta 42$ was capable of acutely inhibiting long-term potentiation (LTP) (Lambert et al., 1998; Chen et al., 2002; Walsh et al., 2002, 2005; Wang et al., 2004; Zhao et al., 2004), one form of synaptic plasticity that is thought to underlie learning and memory (Whitlock et al., 2006). Remarkably, LTP in the hippocampus was inhibited by naturally secreted human $\mathrm{A} \beta$ oligomers when administered in the nanomolar range (Walsh et al., 2002; Wang et al., 2004). Previously, a few reports showed that administration of $\mathrm{A} \beta$ at low micromolar concentrations depressed synaptic transmission by interacting with glutamate receptors (Snyder et al., 2005; Tyszkiewicz and Yan, 2005; Hsieh et al., 2006; Parameshwaran et al., 2007). Together, these results indicate the relevance of identifying cell surface acceptor sites mediating the interaction with oligomeric $\mathrm{A} \beta$ and, as a consequence, activating signal transduction mechanisms contributing to synaptic dysfunction.

The receptor for advanced glycation end products (RAGE), a 
multiligand receptor in the Ig superfamily, functions as a cell surface binding site for $\mathrm{A} \beta$ (Yan et al., 1996). Experimental evidence has shown that RAGE is a receptor that directs the effects of $\mathrm{A} \beta$ to target cells (neurons, glia, endothelial cells) (Yan et al., 1995; Hofmann et al., 1999; Lue et al., 2001; Schmidt et al., 2001; Deane et al., 2003; Lue et al., 2005). Furthermore, introduction of a wild-type (WT) RAGE transgene in neurons in the AD-type transgenic (Tg) mouse model expressing mutant human amyloid precursor protein (mAPP) accelerated $\mathrm{A} \beta$-mediated neuronal perturbation (Arancio et al., 2004).

In the present work, we investigated the effect of oligomeric $\mathrm{A} \beta 42$ at a concentration of $200 \mathrm{nM}$ on LTP, long-term depression (LTD), paired-pulse facilitation, and basal synaptic transmission in entorhinal cortex, an area affected at an early stage of $\mathrm{AD}$ (Braak and Braak, 1991). In addition, we investigated the role of RAGE and signal transduction pathways, p38 and c-Jun N-terminal kinase (JNK) mitogen-activated protein kinases (MAPKs) in $\mathrm{A} \beta$-induced synaptic dysfunction. Finally, we have used a cell culture model to investigate RAGE-triggered signal transduction mechanisms underlying the effects of pathophysiologically relevant concentrations of $\mathrm{A} \beta$ (200 nM), focusing on these key intracellular kinases.

\section{Materials and Methods}

Homozygous RAGE-null and transgenic DN-RAGE mice. Homozygous RAGE-null mice were generated and characterized as described previously (Sakaguchi et al., 2003; Wendt et al., 2003). Homozygous RAGEnull mice were backcrossed for $>10$ generations into the C57BL/6 background. In addition we used transgenic mice with signal transduction deficient mutants of RAGE in which the cytosolic domain of the receptor has been deleted, thereby imparting a dominant-negative (DN)-RAGE effect, targeted to neurons (DN-RAGE) driven by the platelet-derived growth factor-B (PDGF-B) chain promoter. The PDGF-B chain promoter has been successfully used to drive expression of transgene targeted to neurons (Sasahara et al., 1991; Mucke et al., 2000; Lustbader et al., 2004; Takuma et al., 2005). Furthermore, transgenic mice expressing neuronal DN-RAGE driven by the PDGF-B chain promoter have been previously characterized, demonstrating localization of DN-RAGE in cortical neurons (Arancio et al., 2004). Male RAGE-null, male transgenic DN-RAGE and littermate control mice were used for in vitro electrophysiology (age range, 2-3 months) (see below, Slice preparation).

Pharmacologic agents. $\mathrm{A} \beta 42$ and the reversed peptide $\mathrm{A} \beta(42-1)$ were purchased from Biosource (Camarillo, CA). Oligomeric A $\beta 42$ peptide was prepared as described previously, and characterized by atomic force microscopy (Yan et al., 2007) and mass spectrometry (Voyager DE PRO MALDI; Applied Biosystems, Warrington, UK). Aliquots were stored at $-20^{\circ} \mathrm{C}$ in DMSO as a $200 \mu \mathrm{M}$ stock solution and diluted to the desired final concentration in artificial CSF [ACSF; containing (in mM) 119 $\mathrm{NaCl}, 2.5 \mathrm{KCl}, 2 \mathrm{CaCl}_{2}, 1.2 \mathrm{MgSO}_{4}, 1 \mathrm{NaH}_{2} \mathrm{PO}_{4}, 26.2 \mathrm{NaHCO}_{3}, 11$ glucose], immediately before application (Simmons et al., 1994). 4-(4Fluorophenyl)-2-(4-metylsulfinylphenyl)-5-(4-pyridyl)- $1 H$-imidazole (SB203580) and anthra(1-9-cd) pyrazol-6(2H)-one (SP600125) were purchased from Alexis (Grünberg, Germany) and prepared in DMSO stock solutions. These drugs were also diluted to the desired final concentration in ACSF. Specific antibodies to RAGE have been described in our previous studies (Yan et al., 1996) and purified rabbit IgG was used as a control (Bethyl, Montgomery, TX).

Slice preparation. RAGE-null mice, transgenic DN-RAGE mice, and littermate control mice (age range, $2-3$ months) were used. Animals were deeply anesthetized using urethane ( $20 \%$ solution, $0.1 \mathrm{ml} / 100 \mathrm{~g}$ body weight) via intraperitoneal injection and then decapitated after disappearance of the tail pinch reflex. The brain was rapidly removed and thick horizontal sections $(400 \mu \mathrm{m})$ containing the entorhinal area were made on a Vibratome. All steps were performed in ice-cold ACSF solution bubbled with $95 \% \mathrm{O}_{2} / 5 \% \mathrm{CO}_{2}$. Before recording, slices were stored for at least $1 \mathrm{~h}$ in a recovery chamber containing oxygenated ACSF solution at room temperature. During electrophysiological recordings, slices were perfused at a rate of $2.5-3 \mathrm{ml} / \mathrm{min}$ with oxygenated ACSF at $33 \pm 1^{\circ} \mathrm{C}$.

Electrophysiological recordings. Extracellular field potentials (FPs) were evoked in layer III in response to electrical stimulation of layer II (see Fig. $1 A$, schematic diagram). The amplitude of the FPs was used as a measure of the evoked population excitatory current (Domenici et al., 1995; Pesavento et al., 2002). All FPs had peak latency between 4.5 and $6 \mathrm{~ms}$. Amplitudes of FPs were calculated at different stimulus intensities to obtain input-output curves. Experiments to assess paired-pulse stimulation (PP) were performed as well; two consecutive stimuli were applied at different interstimulus intervals $(30-200 \mathrm{~ms})$. PP-induced change was calculated as the ratio of the peak amplitude of the second FP to the first one. Baseline responses were obtained with a stimulation intensity that yielded $50-60 \%$ of maximal amplitude. FP amplitude was monitored every $20 \mathrm{~s}$ and averaged every three responses by online data acquisition software (Anderson and Collingridge, 2001). After $15 \mathrm{~min}$ of stable baseline recording, high-frequency stimulation (HFS; three trains of 100 pulses at $100 \mathrm{~Hz}, 10 \mathrm{~s}$ interval) or low-frequency stimulation (LFS; 900 paired pulses at $1 \mathrm{~Hz}$, the interval between paired pulses was $30 \mathrm{~ms}$ ) (Kourrich and Chapman, 2003) was used to induce LTP or LTD, respectively. LTP and LTD magnitude were measured as the average of FP amplitudes between the 40th and the 50th min after termination of induction protocol. Values were expressed as mean \pm SEM percentage change relative to their mean baseline amplitude. $\mathrm{A} \beta$ peptides were applied by general perfusion for 10 min starting 5 min before HFS and LFS. In experiments using the P38 MAPK inhibitor (SB203580) or JNK inhibitor (SP600125), compounds were continuously perfused over slices starting at least 30 min before HFS or LFS.

Cell culture experiments. Primary cell cultures were prepared as follows: cortex from 0- to 3-d-old mice was dissected. Dissections were performed in $200 \mu \mathrm{M}$ kynurenic acid (Sigma, St. Louis, MO) and $25 \mu \mathrm{M}$ 2-amino-5-phosphonovalerate (Tocris Cookson, Bristol, UK) on ice. Tissue slices were digested with trypsin in the presence of DNAase, blocked with a trypsin inhibitor on ice, and dissociated in medium containing DNAase. Cells were recovered, washed by two successive centrifugations, and plated on glass coverslips coated with $50 \mu \mathrm{g} / \mathrm{ml}$ polyornithine and 2\% Matrigel (Collaborative Research, Bedford, MA) in $35 \mathrm{~mm}$ Nunc (Naperville, IL) Petri dishes. Cells were maintained for $7-10 \mathrm{~d}$ in a $5 \% \mathrm{CO}_{2}$ humidified incubator at $37^{\circ} \mathrm{C}$, in minimum essential medium with Earle's salts and Glutamax I (Invitrogen, Carlsbad, CA) to which 5-10\% fetal bovine serum, $6 \mathrm{mg} / \mathrm{ml}$ D-glucose, $3.6 \mathrm{mg} / \mathrm{ml}$ HEPES, 0.1 $\mu \mathrm{g} / \mathrm{ml}$ biotin, $1.5 \mu \mathrm{g} / \mathrm{ml}$ vitamin B12, $30 \mu \mathrm{g} / \mathrm{ml}$ insulin, and $100 \mu \mathrm{g} / \mathrm{ml}$ bovine transferrin (Sigma) were added. Proliferation of non-neuronal cells was prevented by the addition of $2.5-5.0 \mu \mathrm{M}$ cytosine $\beta$-Darabinofuranoside (Sigma) from the second day in culture. To assess viability, cells were incubated with Hoechst $33342(0.3 \mathrm{ng} / \mathrm{ml})$ and propidium iodide (PI) $(1 \mu \mathrm{g} / \mathrm{ml})$ in culture medium for $1 \mathrm{~h}$ in a $\mathrm{CO}_{2}$ incubator at $37^{\circ} \mathrm{C}$, washed in PBS and mounted on microscope slides; double staining was analyzed with a fluorescence microscope (BC 1083 INV 11722; Nikon, Tokyo, Japan). PI is a polar compound which only enters damaged cell membranes; inside cells, it binds to nucleic acids and becomes brightly red fluorescent. In a separate set of experiments, cell viability was assayed using CytoTox 96 Non-Radioactive Cytotoxicity Assay kit (Promega, Madison, WI) according to the manufacturer's protocol. This assay measures lactate dehydrogenase (LDH) activity through the conversion of a tetrazolium salt into a red formazan product. Relative absorbance was measured at $490 \mathrm{~nm}$ using a microplate reader (Bio-Rad, Hercules, CA). Background LDH release, determined in nontreated/control cultures, was subtracted from all experimental values. Finally, we used an antibody recognizing the active form of Caspase-3 (Promega), as a marker of apoptosis, followed by a secondary anti-rabbit antibody conjugated with Alexa Fluor 488. Apoptotic neurons appeared as green fluorescent cells.

ELISA assay. Quantification of phosphorylated [pTpY180/182] and total p38 MAPK was detected in protein extracts from neuronal cell cultures using two different ELISA kits (Biosource, Camarillo, CA) according to the manufacturer's protocol. Cell pellets were collected, immediately frozen at $-80^{\circ} \mathrm{C}$, and subsequently lysed in cell extraction buffer (10 mм Tris, pH 7.4, 100 mм NaCl, 1 mм EDTA, 1 mм EGTA, 1 

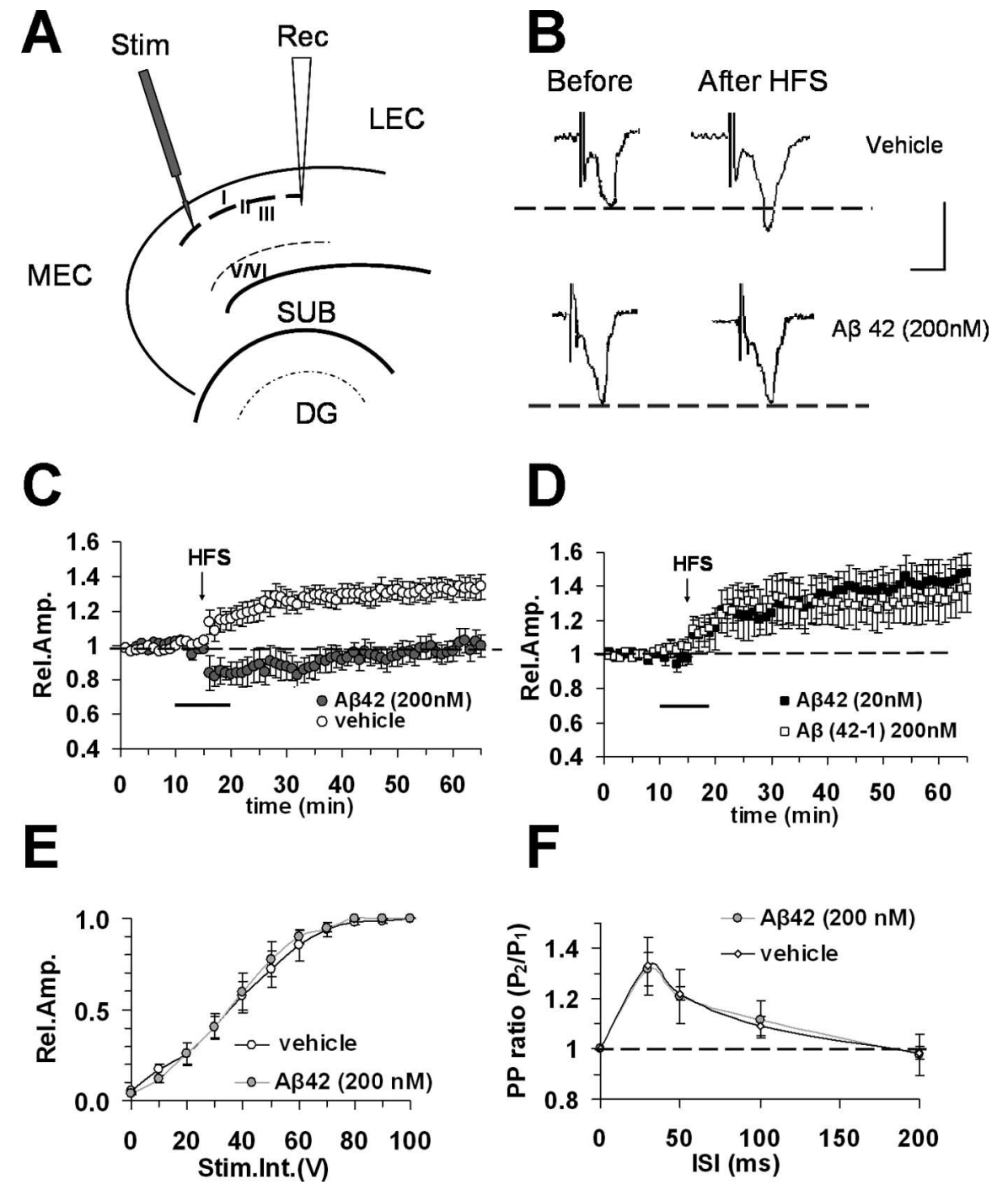

Figure 1. Inhibitory effect of A $\beta 42$ on LTP in entorhinal cortex slices. $A$, Schematic drawing of entorhinal cortex slices and position of electrodes (stimulus position in layer II, recording pipette in layer II/III). MEC, Medial entorhinal cortex; LEC, lateral entorhinal cortex; DG, dentate gyrus; $S U B$, subiculum. $\boldsymbol{B}$, Representative field potentials recorded before and 50 min after HFS in vehicle-treated slices and in slices treated with A $\beta 42$ ( $200 \mathrm{~nm}$ ). Calibration: $1 \mathrm{mV}, 5 \mathrm{~ms}$. Under control conditions LTP expression is induced by HFS, applied after 15 min of baseline recording. C, LTP was induced by HFS stimulation in vehicle-treated slices (open circles), whereas LTP expression was blocked by bath application of A $\beta 42$ ( $200 \mathrm{~nm}$, gray circles) for $10 \mathrm{~min}$ (dark bar). $\boldsymbol{D}$, № effect on LTP expression was observed in the presence of reversed peptide $A \beta(42-1,200 \mathrm{~nm}$, open squares) or a low concentration of A $\beta 42$ ( $20 \mathrm{~nm}$, filled squares). $\boldsymbol{E}$, Input- output curves. The relative amplitude (Rel. Amp.) as a function of stimulus intensity (Stim. Int.) measured in volts $(V)$ did not show significant differences between vehicle-treated (open circles) and $A \beta 42$-treated slices (gray circles). $\boldsymbol{F}$, Paired-pulse facilitation. Paired-pulse-induced change was calculated as the ratio of the peak amplitude of the second evoked field potential to the first one (PP ratio) for different interstimulus intervals $(25-200 \mathrm{~ms})$. PP ratio was not modified in A $\beta 42$ ( $200 \mathrm{~nm}$, gray circles) treated slices respect to vehicle-treated slices (open circles). Error bars indicate SEM.

mu NaF, $20 \mathrm{~mm} \mathrm{Na}_{4} \mathrm{P}_{2} \mathrm{O}_{7}, 2 \mathrm{~mm} \mathrm{Na}_{3} \mathrm{VO}_{4}, 1 \%$ Triton X-100, $10 \%$ glycerol, $0.1 \%$ SDS, $0.5 \%$ deoxycholate, and 1 mm PMSF; Sigma protease mixture inhibitor). The extract was then centrifuged (13,000 rpm, 10 $\min$ at $4^{\circ} \mathrm{C}$ ) to obtain a clear lysate that was used for the assay. Samples were pipetted into wells coated with a specific monoclonal antibody against p38 MAPK (regardless of phosphorylation state); after washing, the detection antibody (rabbit anti-p38 MAPK [pTpY180/182] or rabbit anti-total-p38 MAPK) was added to wells. The sandwich was completed by adding anti-rabbit IgG-HRP conjugated. After completing the reaction with stabilized chromogen (tetramethylbenzidine), absorbance was read at $450 \mathrm{~nm}$ using a microplate reader (Bio-Rad). Values are expressed as 38 MAPK [pTpY180/182] units normalized for the content of total p38 MAPK.

Statistical analysis. Statistical comparisons between experimental groups or between FP amplitudes measured during baseline and after the induction protocol were performed by applying a two-way repeated-measures ANOVA with pairwise multiple comparison procedures (Holm-Sidak method). Comparisons between different groups in cell culture experiments were performed using one-way ANOVA. Differences were considered significant when $p<0.05$.

\section{Results}

Application of oligomeric A $\beta 42$ affects LTP in the entorhinal cortex

We focused our studies on the entorhinal cortex, an area of the brain crucially involved in cognitive and memory processes that is reciprocally connected to the hippocampus and associative cortical areas. In particular, the distribution of its afferent, efferent, and associational projections suggests that different rostrocaudal strips of entorhinal cortex may operate independently in processing neocortex- and hippocampus-originated information (Witter et al., 1989; Dolorfo and Amaral, 1998). We recorded FPs in horizontal sections of entorhinal slices from superficial layer II/III after stimulation of layer II (Fig. $1 A, B$ ). Regarding laminar differentiation, superficial layers (I-III) receive projections from unimodal and polymodal association areas via the perirhinal cortex and then provide the majority of input projections to the hippocampus (Witter et al., 1989). Intrinsic associational fibers originating from superficial layers are confined within the same layers (Dolorfo and Amaral, 1998). Previous studies have shown that in different layers, including superficial layer II/III of the entorhinal cortex, LTP can be elicited (Alonso et al., 1990; Yun et al., 2000) using various stimulus patterns (Yun et al., 2002).

LTP was reliably elicited after HFS in layer II. The mean LTP was 133\% (SEM, $6 \%$ ) of baseline amplitude at $50 \mathrm{~min}$ after HFS ( $n=11$ slices, 6 mice) (Fig. $1 C$ ). When $\mathrm{A} \beta 42$ at $200 \mathrm{~nm}$ (a concentration shown to not cause cell death; see results in cell culture below) was applied for $10 \mathrm{~min}$, starting $5 \mathrm{~min}$ before HFS delivery, in interleaved experiments, LTP expression was completely inhibited ( $98 \pm 6 \%, n=6,4$ mice; $p<0.05$ ) (Fig. $1 C)$. A lower concentration of A $\beta 42$ (20 nM) did not affect LTP $(143 \pm 11 \% ; n=6,3$ mice) (Fig. $1 D)$. LTP amplitude was not affected in slices treated with the reversed peptide $A \beta(42-1)(200$ $\mathrm{nM} ; 134 \pm 14 \% ; n=8,4$ mice) (Fig. $1 D$ ). Impairment of synaptic transmission by $\mathrm{A} \beta 42$ was evaluated by measuring the amplitude of FPs as a function of stimulus intensity. A $\beta 42$ did not change the input-output curve with respect to vehicle-treated slices (Fig. $1 E)$. The latter result, together with absence of baseline modifications by $\mathrm{A} \beta 42$ (Fig. 1C), suggests that synaptic transmission is not impaired by $\mathrm{A} \beta 42$ in accordance with previous reports in hippocampal slices (Chen et al., 2002; Vitolo et al., 2002; Ray- 
mond et al., 2003; Wang et al., 2004). Finally, effects of $\mathrm{A} \beta 42$ on short-term plasticity were assayed using two consecutive electrical stimuli (PP) applied at different interstimulus intervals $(30-200 \mathrm{~ms})$. The $\mathrm{PP}$ ratio was unaffected by $\mathrm{A} \beta 42$ (Fig. $1 F$ ). Therefore, there was no indication that A 342 (200 nM) affects mechanisms of PP facilitation.

\section{RAGE deficiency rescues $\mathrm{A} \boldsymbol{\beta} 42$-induced inhibition of LTP in the \\ entorhinal cortex}

RAGE is a key cofactor mediating $A \beta$ induced synaptic plasticity impairment in the hippocampus (Arancio et al., 2004). To test whether RAGE was involved in A $\beta 42$ entorhinal cortex impairment of LTP, we examined the effect of a brief application of A $\beta 42$ on LTP in cortical slices from RAGE-null mice and in slices from WT mice pretreated with anti-RAGE IgG. Input-output curves (Fig. 2A, left), as well as short-term plasticity properties (PP ratio) (Fig. $2 A$, right), did not differ between RAGE-null slices and anti-RAGE IgG-treated slices from WT mice. The latter two demonstrated the same results as cortical slices from age-matched WT mice exposed to vehicle alone. Moreover, deficiency of RAGE (RAGE-null mice) and blockade of RAGE by specific antibodies to the receptor (WT slices incubated with anti-RAGE IgG, $2.5 \mu \mathrm{g} / \mathrm{ml}$ for at least $2 \mathrm{~h}$ before recordings) did not affect LTP (Fig. $2 B)$. The mean LTP amplitude in RAGEnull mice ( $135 \pm 11 \% ; n=8,4$ mice $)$ and in slices from WT mice treated with antiRAGE IgG ( $131 \pm 6 \%$; $n=5,3$ mice $)$ was not significantly different with respect to vehicle-treated WT slices, suggesting that blockade of RAGE does not affect LTP in entorhinal cortex. Remarkably, when A $\beta 42$ (200 nM) was bath applied to RAGEnull and anti-RAGE IgG-treated WT slices, LTP was normal (Fig. 2C). The mean LTP amplitude measured in RAGEnull ( $126 \pm 2 \% ; n=8,5$ mice $)$ and anti-

RAGE IgG-incubated (136 $\pm 7 \% ; n=6,4$ mice) WT slices treated with $\mathrm{A} \beta 42$ was significantly increased $(p<0.05)$ with respect to LTP in slices treated with A $\beta 42$ alone (control) (Fig. $2 C$ ). In contrast, values of LTP amplitude were similar in RAGEnull slices or anti-RAGE IgG-treated WT slices without A $\beta$.

Because RAGE is expressed in neurons as well as in other cells (glial cells, endothelial cells) (Schmidt et al., 2001; Lue et al., 2005 ), we determined whether neuronal RAGE is responsible for A $\beta$ effects on LTP in entorhinal cortex. We investigated transgenic mice with signal transduction deficient mutants of RAGE in which the cytosolic domain of the receptor has been deleted, thereby imparting a dominant-negative phenotype, targeted to neurons (DN-RAGE) by the PDGF-B chain promoter. The PDGF-B chain promoter has been successfully used to drive expression of transgene targeted to neurons (Sasahara et al., 1991;
Mucke et al., 2000; Lustbader et al., 2004; Takuma et al., 2005). Furthermore, transgenic mice expressing neuronal DN-RAGE driven by the PDGF-B chain promoter have been previously characterized, demonstrating localization of DN-RAGE in cortical neurons (Arancio et al., 2004). Previous studies revealed that these transgenic mice displayed preservation of spatial learning and memory and decreased neuropathological changes when bred into transgenic mice expressing mutant APP (Arancio et al., 2004). Similar to what was observed in slices from RAGE-null mice, LTP was unaffected in slices from transgenic mice with defective RAGE targeted to neurons (DN-RAGE slices: $136 \pm$ $10 \%, n=9,5$ mice; not significantly different from vehicletreated WT slices) (Fig. $2 D$ ). Most importantly, defective RAGE signaling targeted to neurons protected against $\mathrm{A} \beta$-mediated reduction of LTP (DN-RAGE) (Fig. 2E); LTP values in DN-RAGE 

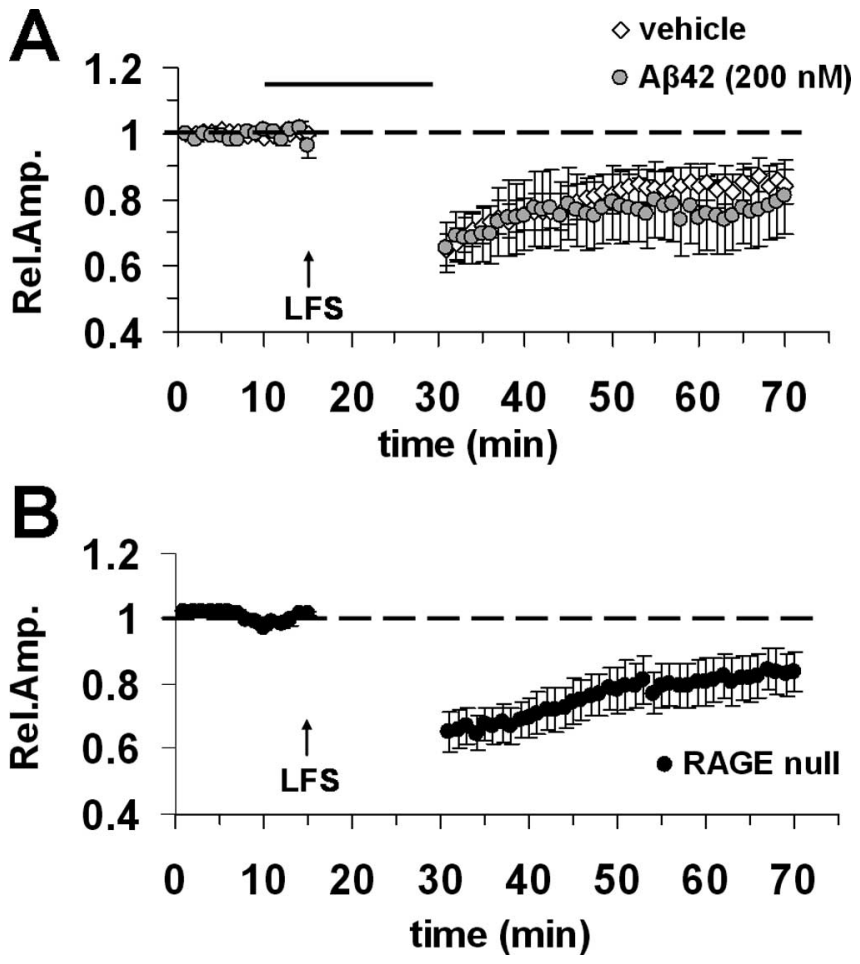

Figure 3. LTD is not affected in entorhinal cortex slices treated with A 342 . $A$, LTD was reliably inducible by LFS (arrow) in vehicle-treated slices (open circles) and $A \beta 42$-treated slices from WT mice (A $\beta 42,200 \mathrm{~nm}$; gray circles). The top horizontal dark bar corresponds to bath applied A $\beta 42$. B, LTD was unimpaired in slices from RAGE-null mice. Error bars indicate SEM.

slices $(127 \pm 5 \% ; n=8,5$ mice $)$ in the presence of $\mathrm{A} \beta 42(200 \mathrm{nM})$ were significantly increased $(p<0.05)$ with respect to slices from WT mice treated with $200 \mathrm{nM} \mathrm{A} \beta$. Thus, functionless RAGE in neurons was able to abolish $\mathrm{A} \beta$ inhibition of LTP.

Based on a previous observations in double knock-in mice carrying human mutations in the genes for APP and presenilin-1 showing that LTD was impaired, in addition to LTP (Chang et al., 2006; but see Wang et al., 2002, showing no effect of exogenous synthetic $\mathrm{A} \beta 42$ on hippocampal LTD), we conducted a complementary study on the effects of A $\beta 42$ on LTD in entorhinal cortex slices. LTD was reliably induced using paired-pulse LFS in agreement with the report by Kourrich and Chapman (2003). After this induction protocol, LTD magnitude was $84 \pm 5 \%(n=10$ slices, 4 mice) (Fig. 3A). Consistent with data obtained by Wang et al. (2002) in hippocampus, A $\beta 42$ (200 nM) did not affect LTD in entorhinal cortex $(77 \pm 10 \% ; n=9$ slices, 4 mice) (Fig. $3 A$ ) ( $p>0.05$ vs control vehicle-treated slices). Moreover, when we tested LTD in RAGE-null slices, we found LTD to be normal (Fig. $3 B$ ) indicating that RAGE deficiency does not affect LTD expression in entorhinal cortex. Thus, LTD induced by LFS is not impaired by $A \beta 42-$ RAGE signaling.

\section{A $\beta 42$ impairment of LTP is prevented by inhibition of p38 MAPK but not JNK}

Stress-related protein kinases, such as JNK and p38 MAPK, are activated in several pathologic processes, including AD neurodegeneration and $A \beta 42$ cytotoxicity (Pei et al., 2001; Troy et al., 2001; Zhu et al., 2005). It is noteworthy that both JNK and p38 MAPK inhibition prevented $A \beta$-induced LTP impairment in hippocampal slices (Wang et al., 2004). These observations suggested the hypothesis that RAGE/A $\beta$ interaction induced impairment of LTP through activation of specific kinase signaling cas- cades. To evaluate this hypothesis, we tested the effect of MAPK inhibitors on development of LTP in cortical slices. In particular, we used a JNK inhibitor (SP600125) and a p38 MAPK inhibitor (SB203580). SB203580 is a cell permeable inhibitor of p38 MAPK $\left(\mathrm{IC}_{50}, 0.3 \mu \mathrm{M}\right)$ showing a high selectivity at concentrations $<2 \mu \mathrm{M}$ (Lali et al., 2000). SP600125 is a potent selective and reversible JNK inhibitor $\left(\mathrm{IC}_{50}, 0.19 \mu \mathrm{M}\right)$ (Bennett et al., 2001). Perfusion with either compound did not induce significant change in FP amplitude during baseline recordings in entorhinal cortex slices (Fig. 4A). When entorhinal cortex slices were continuously perfused with ACSF containing SB203580 (1 $\mu \mathrm{M})$ and SP600125 (20 $\mu \mathrm{M})$, LTP was normally expressed after HFS stimulation (131 \pm $10 \%, n=6,4$ mice, and $146 \pm 11 \%, n=6,4$ mice, respectively; not significantly different with respect to control LTP in vehicletreated slices) (Fig. 4A). Perfusion of the p38 inhibitor $(\mathrm{SB} 203580,1 \mu \mathrm{M})$ in the presence of $\mathrm{A} \beta 42$ (200 $\mathrm{nM}$, for $10 \mathrm{~min}$ starting from 5 min before HFS delivery) restored normal LTP $(136 \pm 13 \% ; n=7,4$ mice; $p<0.05$ vs A $\beta 42$ alone) (Fig. $4 B$ ). LTP amplitude was not significantly different between SB203580-treated and vehicle-treated slices ( $p>0.05)$. In contrast, a specific inhibitor of JNK (SP600125, $20 \mu \mathrm{M})$ failed to rescue LTP in A $\beta 42$-treated slices ( $95 \pm 3 \% ; n=6,3$ mice) (Fig. $4 B$ ). Input-output curves (Fig. $4 C$ ), as well as short-term plasticity properties (PP ratio) (Fig. $4 D$ ), did not differ between SB203580- $(1 \mu \mathrm{M})$ or SP600125 $(20 \mu \mathrm{M})$-treated slices and agematched vehicle-treated WT slices.

\section{A $\beta 42$ increases p38 MAPK phosphorylation in cultured neurons}

To further investigate the effect of RAGE-dependent activation of p38 MAPK on A $\beta$-mediated neuronal dysfunction, we measured levels of p38 MAPK in primary cortical cultures. p38 MAPK is activated by a variety of extracellular stimuli, including $\mathrm{A} \beta$ peptides, and is modulated by several upstream MAPK kinases (MKK3, MKK4, MKK6), which phosphorylate p38 at threonine 180 and tyrosine 182 in the TGY motif (Ono and Han, 2000). Phospho-p38[pTpY180/182] was measured in primary cultures of mouse cortical neurons after exposure to $A \beta 42$ after different incubation times and a range of concentrations. The kinetic profile of p38 activation under these conditions (A $\beta 42,200 \mathrm{~nm}$ ) demonstrated an apparent maximum level of phosphorylation after $10 \mathrm{~min}$. Increasing incubation time to $1 \mathrm{~h}$ did not produce any additional change in phospho-p38 (Fig. $5 A$ ). When neurons were incubated with different concentrations of $A \beta 42$ for $10 \mathrm{~min}$ (2 nM-20 $\mu \mathrm{M}$ ), we found a significant increase in phospho-p38 starting from a concentration of $200 \mathrm{nM}$, compared with vehicletreated control cultures $(88 \pm 12.7$ vs $28.1 \pm 18.7 \mathrm{U} / \mathrm{ng}$ total p38; $p<0.001$ ) (Fig. $5 B, C$ ). Additional increases in $\mathrm{A} \beta 42$ (2 and 20 $\mu \mathrm{M})$ did not induce significantly higher phosphorylation of $\mathrm{p} 38$ (Fig. $5 B$ ). Low concentrations of $\mathrm{A} \beta$ ( 2 and $20 \mathrm{~nm}$ ) did not produce any increase in phospho-p38 (Fig. $5 B$ ). Thus, $A \beta$ is able to activate $\mathrm{p} 38 \mathrm{MAPK}$ at a concentration and with application times in culture comparable with conditions in LTP experiments.

To determine the effect of RAGE on activation of $\mathrm{p} 38$ induced by $\mathrm{A} \beta$, we have performed experiments with blocking anti-RAGE antibodies in cell culture. When cells were pretreated with antiRAGE IgG $(2.5 \mu \mathrm{g} / \mathrm{ml})$ for $2 \mathrm{~h}$ before exposure to $\mathrm{A} \beta$, levels of phosho-p38 were significantly reduced compared with neurons incubated with $\mathrm{A} \beta$ alone ( $44.3 \pm 7.4$ vs $88 \pm 12.7 \mathrm{U} / \mathrm{ng}$ total $\mathrm{p} 38$; $p<0.05$, Fig. $5 C$ ). However, when anti-RAGE IgG was replaced by nonimmune IgG (control, rabbit IgG), levels of phospho-p38 in $\mathrm{A} \beta$-treated cells were not decreased and remained significantly higher in comparison with those of vehicle-treated control cells 
(91.9 \pm 13 vs $28 \pm 18.7 \mathrm{U} / \mathrm{ng}$ total p38, Fig. $5 C$ ). These results suggest that blocking RAGE by administration of anti-RAGE IgG suppressed A $\beta$ mediated activation of p38. Furthermore, we used hydrogen peroxide $\left(\mathrm{H}_{2} \mathrm{O}_{2}\right)$ in the incubation medium ( $10 \mathrm{~min}$ at $100 \mu \mathrm{M}$ ) to activate p38 to estimate maximal levels of phospho-p38 and to examine whether $\mathrm{H}_{2} \mathrm{O}_{2}$-induced activation of p38 might also be mediated by RAGE. Under the latter conditions (dose and time of exposure to $\mathrm{H}_{2} \mathrm{O}_{2}$ ), cultured cortical neurons displayed activation of p38 MAPK in the absence of cytotoxicity (Wang et al., 2003). Indeed, we found that $\mathrm{H}_{2} \mathrm{O}_{2}$ significantly increased phospho-p38 with respect to control cultures $(110 \pm 20.2 \mathrm{U} / \mathrm{ng}$ total p38, $p<0.001$ vs vehicle-treated cultures; $p=$ 0.3 vs $A \beta$-treated cultures) (Fig. $5 C$ ). Importantly, anti-RAGE IgG did not block increased levels of phospho-p38 induced by $\mathrm{H}_{2} \mathrm{O}_{2}(118.6 \pm$ 5.4 vs $110 \pm 20.2$ in cultures incubated with $\mathrm{H}_{2} \mathrm{O}_{2}$, Fig. 5 C). Administration of nonimmune IgG alone did not affect baseline levels of phospho-p38 (Fig. 5C). These results further support the concept that $A \beta$-mediated activation of p38 MAPK occurred as a downstream consequence of RAGE-A $\beta$ interaction.

In additional experiments, we assessed whether A $\beta 42$ (200 nM) induced cell death using two different methods: $1 \mathrm{~h}$ incubation with PI and a biochemical assay measuring LDH activity (supplemental Fig. 1, available at www.jneurosci.org as supplemental material). No evidence of cell death was observed with $200 \mathrm{~nm}$ A $\beta 42$ using either of these methods. In addition, immunocytochemical analysis with an antibody to the activated form of caspase-3 (a marker of apoptosis) showed that $A \beta 42(200 \mathrm{~nm})$ did not significantly increase the number of apoptotic cells even with prolonged $\mathrm{A} \beta$ incubation (supplemental Fig. 2, available at www.jneurosci.org as supplemental material).

Together, these results obtained with cultured neurons revealed that (1) $A \beta$ is able to activate $\mathrm{p} 38$ MAPK when applied at $\mathrm{nm}$ concentrations, and (2) the increase in phospho-p38 can be prevented by blocking RAGE. Furthermore, it is plausible that RAGE-mediated activation of $\mathrm{p} 38$ MAPK in neurons after exposure to $A \beta 42$ might represent a cellular mechanism accounting for LTP impairment.

\section{Discussion}

Oligomeric forms of $A \beta$ play a critical role in the pathogenesis of $\mathrm{AD}$. In particular, $A \beta$ is believed to contribute to early impairment of cognitive functions such as learning and memory (Cleary et al., 2005; Lesne et al., 2006). Such early signs of functional impairment precede extensive neurodegeneration characteristic of the middle/late phase of $\mathrm{AD}$, which includes extensive deposition of amyloid in the form of plaques. Although not completely clear, the mechanism underlying early functional impairment is likely to involve perturbation of synapse efficacy in different brain areas in the presence of an environment with increased extracellular levels of $\mathrm{A} \beta$. Consistent with this hypothesis, oligomeric $A \beta$ affects long-term forms of synaptic plasticity, such as LTP in the hippocampus (Lambert et al., 1998; Chen et al., 2002; Vitolo et al., 2002; Wang et al., 2004; Puzzo et al., 2005), a brain
B
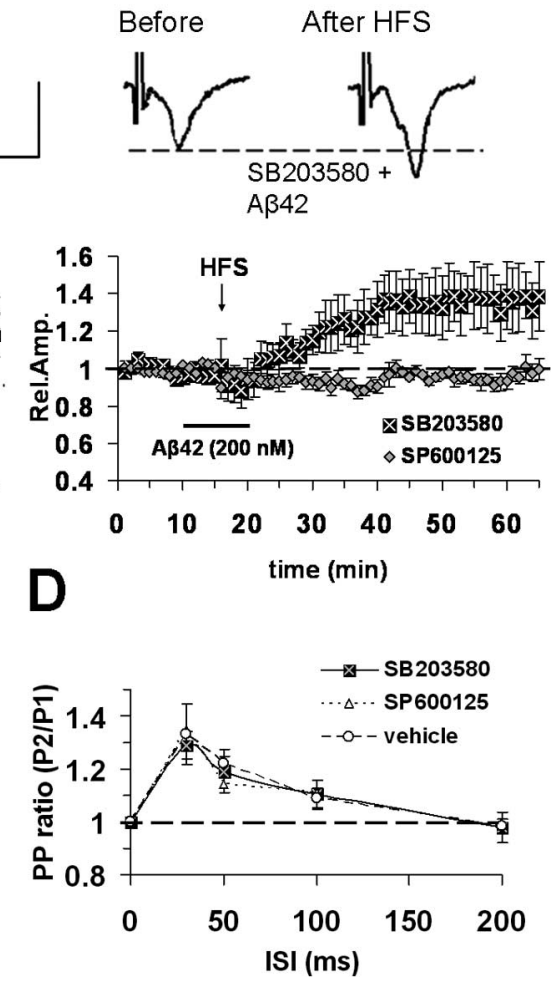
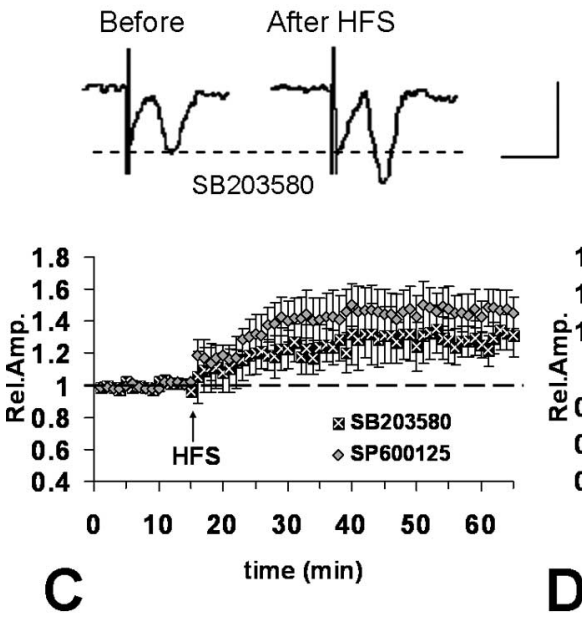

4. $A \beta 42$ impairment of LTP is prevented by inhibition of p38 MAPK, but not JNK in entorhinal cortex slices MAPK inhibitor) (filled square) or $20 \mu \mathrm{M}$ SP600125 (JNK inhibitor) (gray diamonds). Top, Representative field potentials Red L blockade in A $\beta 42$-treated slices (bath application at $200 \mathrm{~nm}$ corresponding to dark bar). Top or $20 \mu \mathrm{m}$ SP600125 (open triangles) did not change the input- output curves with respect to vehicle-treated slices (open circles). D, Paired-pulse facilitation, PP ratio was not modified in $1 \mu \mathrm{m}$ SB203580- and $20 \mu \mathrm{m}$ SP600125-treated slices with respect to vehicle-treated slices; other conventions are as in $C$. Error bars indicate SEM.

area fundamentally involved in learning and memory. We have focused our work on entorhinal cortex slices, because this region is a major locus of information exchange between the hippocampus and other cortical areas (Witter et al., 1989; Braak and Braak, 1993; Suzuki and Amaral, 2004) that is also affected at an early stage of AD (Braak and Braak, 1991). In addition, synaptic transmission and long-term synaptic plasticity in the forms of LTP and LTD are well characterized in the entorhinal cortex layers (Alonso et al., 1990; Yun et al., 2000, 2002; Kourrich and Chapman, 2003) representing a suitable assay to probe neuronal function.

Our experiments indicate that oligomeric $\mathrm{A} \beta 42$, at a concentration of $200 \mathrm{nM}$, is capable of blocking LTP, but not LTD or PP, at cortical synapses in the entorhinal cortex. The present results in the entorhinal cortex confirm previous data obtained in hippocampus, which showed that oligomeric $A \beta$ impairs LTP (Walsh et al., 2002, 2005; Wang et al., 2004). Also, our results are in agreement with Wang et al. (2002), who showed that soluble $\mathrm{A} \beta$ inhibited LTP in the hippocampus without affecting LTD. Thus, it is likely that even brief exposure to $200 \mathrm{~nm} \mathrm{~A} \beta 42$ specifically perturbs LTP in the entorhinal cortex. In contrast, $A \beta 42$ at the same concentration did not induce a concomitant impairment of synaptic transmission as evaluated by input-output functions and baseline neurotransmission. A few reports have 

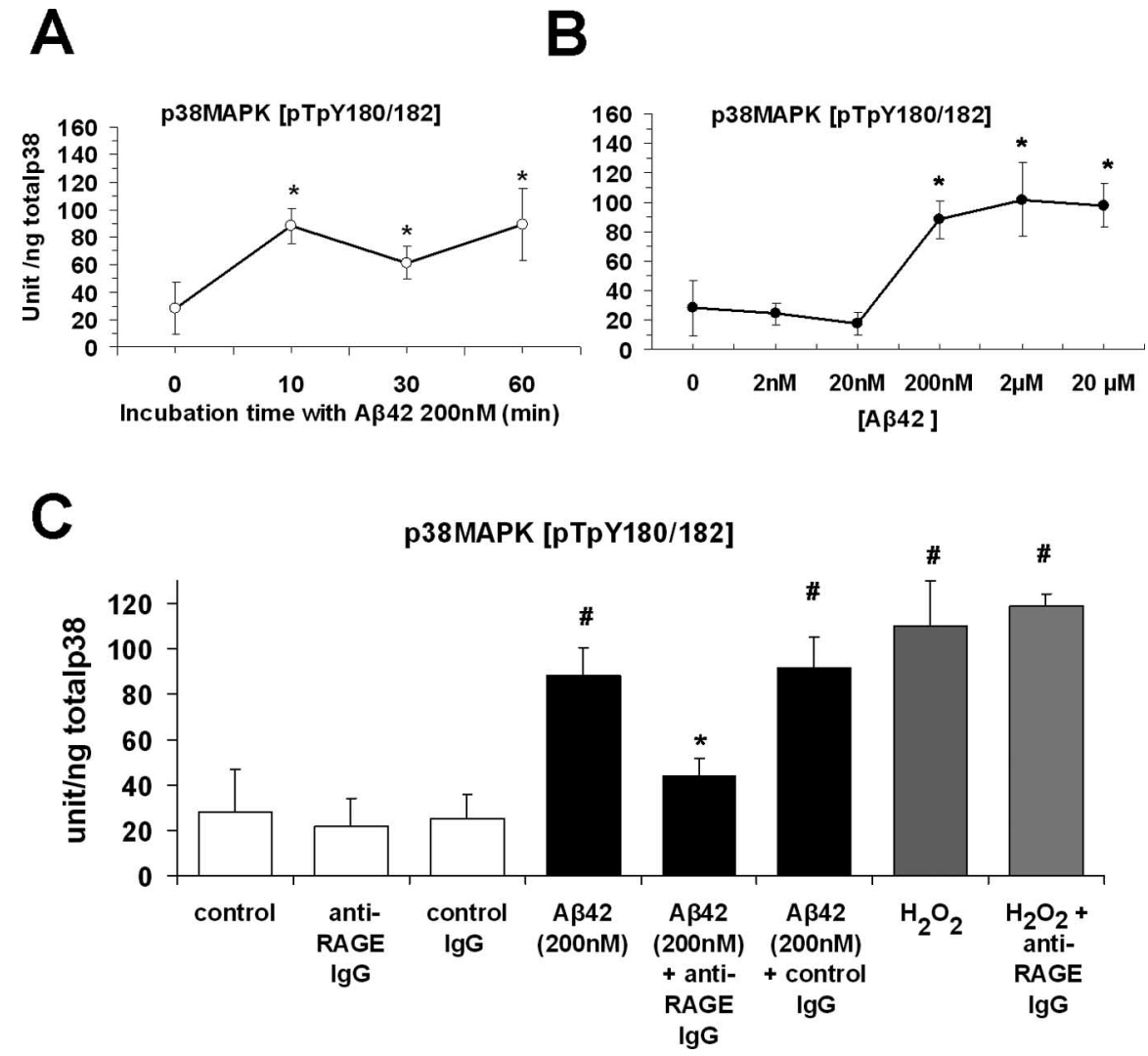

Figure 5. $\mathrm{p} 38 \mathrm{MAPK}$ phosphorylation increased in cultured neurons exposed to a nontoxic concentration of $\mathrm{A} \beta 42$. $A$, Effect of A $\beta 42$ (200 nM) on p38 phosphorylation at different incubation times ( $n=6$ experiments for each group; ${ }^{*} p<0.05$ vs control untreated cells). $\boldsymbol{B}$, Effect of increasing concentrations of $A \beta 42$ on p38 phosphorylation; $200 \mathrm{~nm} A \beta 42$ significantly increased phospho-p38 levels ( $n=6$ experiments in each group, ${ }^{*} p<0.001$ vs control untreated). No additional increase was induced by higher concentrations $A \beta 42$ (2 and $20 \mu \mathrm{m})$. C, $A \beta 42$ (200 nM, 10 min incubation) or $\mathrm{H}_{2} \mathrm{O}_{2}(100 \mu \mathrm{m}, 10 \mathrm{~min}$ ) increased p38 phosphorylation compared with anti-RAGE IgG. Levels of $\mathrm{p} 38$ phosphorylation in cultures exposed to $A \beta 42$ in the presence of anti-RAGE IgG were similar to those observed in cultures not exposed to $A \beta 42$ and incubated with control lgG or in control cells $\left({ }^{\#} p<0.001\right)$. Anti-RAGE IgG pretreatment of neuronal cultures significantly reduced $A \beta$-, but not $\mathrm{H}_{2} \mathrm{O}_{2}$-induced increase in phospho-p38 (* $p<0.05$ vs A $342200 \mathrm{~nm} ; n=6$ experiments for each group). Error bars indicate SEM.

shown that administration of $\mathrm{A} \beta$ at low $\mu \mathrm{M}$ concentrations (i.e., at concentrations higher than that used in the present work) can depress synaptic transmission by regulating glutamate receptors trafficking (Snyder et al., 2005; Tyszkiewicz and Yan, 2005; Hsieh et al., 2006; Parameshwaran et al., 2007). Moreover, higher levels of $\mathrm{A} \beta$, thought to be present in intermediate/late stages of neurodegeneration, may affect synaptic transmission and LTD in addition to LTP by regulating trafficking of AMPA- and/or NMDA-receptors (Hsia et al., 1999; Oddo et al., 2003; Chang et al., 2006; Shemer et al., 2006). Interestingly, studies conducted in animal models of AD characterized by progressive accumulation of $A \beta 42$ have shown that LTP disruption occurs before deficits in basal transmission (Trinchese et al., 2004; Chang et al., 2006) and LTD (Chang et al., 2006). Thus, these results in animal models of $\mathrm{AD}$ and synthetic $\mathrm{A} \beta$ lend support to the concept that impaired LTP characterizes an early stage in AD progression corresponding to a low $\mathrm{A} \beta$ load. Later stages in $\mathrm{AD}$ progression are associated with a greater $A \beta$ load and also affect basal synaptic transmission and LTD.

Concerning the possible cell surface receptors that are able to bind $\mathrm{A} \beta$ and activate downstream intracellular cascades leading to LTP impairment, a number of studies have identified RAGE as a receptor capable of binding to $\mathrm{A} \beta$, in monomeric, fibrillized, and oligomeric form (for review, see Ding and Keller, 2005) (S. D.
Yan, unpublished observation) at the cell surface (Lue et al., 2001). RAGE immunoreactivity is present at sites of $A \beta$ deposition and binding of $A \beta$ is considered an important event, increasing $A \beta$ aggregation at the cell membrane (Yan et al., 1996, 1998). This viewpoint assigns an important role for $A \beta$ engagement of RAGE in downstream signaling and effector mechanisms leading to oxidative stress, inflammation, and neurotoxicity. Moreover, RAGE has been implicated as an important cofactor for $\mathrm{A} \beta$-induced neuronal dysfunction in a murine model of $\mathrm{AD}$ ( $\mathrm{Tg}$ APP mice). Indeed, hippocampal LTP was altered only in double-Tg mice (expressing RAGE/mutant APP transgenes) and not in single Tg mice (mutant APP or RAGE), suggesting that overexpression of RAGE in an $A \beta$-rich environment perturbs synaptic efficacy (Arancio et al., 2004). In the present study, we found that RAGE deficiency or functional blockade of RAGE by specific antibodies counteracts LTP dysfunction induced by $\mathrm{A} \beta 42$. Because RAGE is expressed in neurons, as well as other cells critical for neurodegenerative pathology (glial cells, endothelial cells and pericytes of the blood-brain barrier) (Schmidt et al., 2001; Lue et al., 2005), we sought to determine whether neuronal RAGE was responsible for $\mathrm{A} \beta$ dependent LTP impairment in entorhinal cortex. To shed light on this issue, we made use of transgenic mice with a signal transduction deficient mutant of RAGE in which the cytosolic domain of the receptor had been deleted, thereby imparting a DN-RAGE effect. The latter transgene was targeted to neurons (DN-RAGE) by the PDGF-B chain promoter. Previous data reported that expression of DN-RAGE, even in cells expressing wild-type RAGE, blocked RAGEdependent cellular activation (Hofmann et al., 1999; Arancio et al., 2004). Our findings clearly showed that entorhinal cortex slices from DN-RAGE transgenic mice were resistant to disruption of LTP by $200 \mathrm{~nm} \mathrm{~A} \beta$, suggesting the involvement of neuronal RAGE in mechanisms leading to $\mathrm{A} \beta$-induced cortical inhibition of LTP. Our results do not exclude that non-neuronal RAGE (RAGE expressed in glial cells, endothelial cells and pericytes of the blood-brain barrier) might be involved in synaptic dysfunction associated with oxidative stress, inflammation, and neurotoxicity characterizing $\mathrm{AD}$ progression, as suggested by a previous study (Lue et al., 2001). In perspective, it will be interesting to investigate the role of non-neuronal RAGE in synaptic failure induced by $\mathrm{A} \beta$.

Signaling cascades activated after ligand-RAGE interaction include pathways such as p21ras, extracellular signal-regulated kinase 1/2 (p44/p42) MAP kinases, p38 MAPK and SAPK (stressactivated protein kinase)/JNK, Rho GTPases, phosphoinositol-3 kinase, and the JAK/STAT (signal transducer and activator of transcription) pathway. Downstream consequences, such as the activation of the key transcription factors, nuclear factor- $\kappa \mathrm{B}$ and CREB (cAMP response element binding protein), have also been 
reported previously (Lander et al., 1997; Deora et al., 1998; Hofmann et al., 1999; Huttunen et al., 1999; Kislinger et al., 1999; Huang et al., 2001). Activation of different protein kinase cascades is a principal target of RAGE activation in the pathway controlling synaptic plasticity. In particular, we considered two different kinases, namely JNK and p38 MAPK as potentially involved in inhibition of LTP. Recent results showed that p38 MAPK and JNK activation are required for LTP inhibition induced by proinflammatory agents such as interleukin- $1 \beta$ and lipopolysaccharide (Curran et al., 2003; Kelly et al., 2003). These results prompted us to test whether p38 MAPK and JNK were involved in LTP inhibition by $\mathrm{A} \beta$. In contrast to inflammatory stimuli, A $\beta$ induced LTP impairment could be prevented by a p38 MAPK inhibitor alone, suggesting that activation of this downstream kinase is a key event in the $\mathrm{A} \beta$-initiated signaling pathway. Our results are in agreement with previous data obtained in the RAGE/mutant APP double-transgenic mice that showed a role for RAGE in the activation of p38 MAPK in the hippocampus during AD-like neurodegeneration (Arancio et al., 2004). Although, the role of $\mathrm{p} 38 \mathrm{MAPK}$ in the pathogenesis of AD has been well established (Hensley et al., 1999; Zhu et al., 2005), we also investigated the role of another major stress-activated protein kinase, namely, JNK. However, inhibition of JNK with SP600125 was ineffective in rescuing cortical LTP after treatment of entorhinal cortex slices from WT mice with $\mathrm{A} \beta$. According to the work of others, inhibition of JNK only partially rescued LTP after the application of synthetic $A \beta 42$ peptide in the hippocampus (Wang et al., 2004), leading us to conclude that $\mathrm{A} \beta$-induced inhibition of LTP may occur via a proinflammatory pathway that is principally controlled by activation of p38 MAPK. These observations are further supported by our results showing that A $\beta 42$ at nontoxic concentrations was able to phosphorylate p38 MAPK in cultured cortical neurons. In contrast, addition of antiRAGE IgG to neuronal cultures prevented A $\beta 42$-mediated activation of $\mathrm{p} 38$ MAPK. However, delineation of the precise route from $\mathrm{p} 38$ MAPK phosphorylation to the key substrate(s) leading to $A \beta$-dependent LTP impairment has yet to be identified.

Together, our results indicate that neuronal RAGE is involved in mechanisms underlying $\mathrm{A} \beta$-induced inhibition of LTP, at least in part, through activation of p38 MAPK in mouse cortex. This work contributes to an increasing body of evidence that activation of RAGE by oligomeric $A \beta$ represents an important early step in neuronal dysfunction before amyloid plaque deposition. Thus, RAGE activation by $\mathrm{A} \beta$ may lead to an early impairment of cognitive functions in brain areas critically affected in AD.

\section{References}

Alonso A, de Curtis M, Llinas R (1990) Postsynaptic Hebbian and nonHebbian long-term potentiation of synaptic efficacy in the entorhinal cortex in slices and in the isolated adult guinea pig brain. Proc Natl Acad Sci USA 87:9280-9284.

Anderson WW, Collingridge GL (2001) The LTP program: a data acquisition program for on-line analysis of long-term potentiation and other synaptic events. J Neurosci Methods 108:71-83.

Arancio O, Zhang HP, Chen X, Lin C, Trinchese F, Puzzo D, Liu S, Hegde A, Yan SF, Stern A, Luddy JS, Lue LF, Walker DG, Roher A, Buttini M, Mucke L, Li W, Schmidt AM, Kindy M, Hyslop PA, et al. (2004) RAGE potentiates $\mathrm{A} \beta$-induced perturbation of neuronal function in transgenic mice. EMBO J 23:4096-4105.

Bennett BL, Sasaki DT, Murray BW, O’Leary EC, Sakata ST, Xu W, Leisten JC, Motiwala A, Pierce S, Satoh Y, Bhagwat SS, Manning AM, Anderson DW (2001) SP600125, an anthrapyrazolone inhibitor of Jun N-terminal kinase. Proc Natl Acad Sci USA 98:13681-13686.

Braak H, Braak E (1991) Demonstration of amyloid deposits and neurofibrillary changes in whole brain sections. Brain Pathol 3:213-216.
Braak H, Braak E (1993) Entorhinal-hippocampal interaction in mnestic disorders. Hippocampus 3:239-246.

Chang EH, Savage MJ, Flood DG, Thomas JM, Levy RB, Mahadomrongkul V, Shirao T, Aoki C, Huerta PT (2006) AMPA receptor downscaling at the onset of Alzheimer's disease pathology in double knock-in mice. Proc Natl Acad Sci USA 103:3410-3415.

Chapman PF, White GL, Jones MW, Cooper-Blacketer D, Marshall VJ, Irizarry M, Younkin L, Good MA, Bliss TV, Hyman BT, Younkin SG, Hsiao KK (1999) Impaired synaptic plasticity and learning in aged amyloid precursor protein transgenic mice. Nat Neurosci 2:271-276.

Chen QS, Wei WZ, Shimahara T, Xie CW (2002) Alzheimer amyloid betapeptide inhibits the late phase of long-term potentiation through calcineurin-dependent mechanisms in the hippocampal dentate gyrus. Neurobiol Learn Mem 77:354-371.

Cleary JP, Walsh DM, Hofmeister JJ, Shankar GM, Kuskowski MA, Selkoe DJ, Ashe KH (2005) Natural oligomers of the amyloid-beta protein specifically disrupt cognitive function. Nat Neurosci 8:79-84.

Curran BP, Murray HJ, O'Connor JJ (2003) A role for c-Jun N-terminal kinase in the inhibition of long-term potentiation by interleukin- $1 \beta$ and long-term depression in the rat dentate gyrus in vitro. Neuroscience 118:347-357.

Deane R, Du Yan S, Submamaryan RK, LaRue B, Jovanovic S, Hogg E, Welch D, Manness L, Lin C, Yu J, Zhu H, Ghiso J, Frangione B, Stern A, Schmidt AM, Armstrong DL, Arnold B, Liliensiek B, Nawroth P, Hofman F, et al. (2003) RAGE mediates amyloid-beta peptide transport across the bloodbrain barrier and accumulation in brain. Nat Med 9:907-913.

Deora A, Win T, Vanhaesebroeck B, Lander H (1998) A redox triggered Ras-effector interaction: recruitment of phosphatidyli-nositol 30-kinase to Ras by redox stress. J Biol Chem 273:29923-29928.

D’Hooge R, Nagels G, Westland CE, Mucke L, De Deyn PP (1996) Spatial learning deficit in mice expressing human 751-amino acid beta-amyloid precursor protein. NeuroReport 7:2807-2811.

Ding Q, Keller JN (2005) Evaluation of rage isoforms, ligands, and signaling in the brain. Biochim Biophys Acta 1746:1 8-27.

Dolorfo CL, Amaral DG (1998) Entorhinal cortex of the rat: organization of intrinsic connections. J Comp Neurol 398:49-82.

Domenici L, Harding GW, Burkhalter A (1995) Patterns of synaptic activity in forward and feedback pathways within rat visual cortex. J Neurophysiol 74:2649-2664.

Eisenhauer PB, Johnson RJ, Wells JM, Davies TA, Fine RE (2000) Toxicity of various amyloid beta peptide species in cultured human blood-brain barrier endothelial cells: increased toxicity of dutch-type mutant. J Neurosci Res 60:804-810.

Giacchino J, Criado JR, Games D, Henriksen S (2000) In vivo synaptic transmission in young and aged amyloid precursor protein transgenic mice. Brain Res 876:185-190.

Hensley K, Floyd RA, Zheng NY, Nael R, Robinson KA, Nguyen X, Pye QN, Stewart CA, Geddes J, Markesbery WR, Patel E, Johnson GV, Bing G (1999) p38 kinase is activated in the Alzheimer's disease brain. J Neurochem 72:2053-2058.

Hofmann MA, Drury S, Fu C, Qu W, Taguchi A, Lu Y, Avila C, Kambham N, Bierhaus A, Nawroth P, Neurath MF, Slattery T, Beach D, McClary J, Nagashima M, Morser J, Stern D, Schmidt AM (1999) RAGE mediates a novel proinflammatory axis: a central cell surface receptor for S100/calgranulin polypeptides. Cell 97:889-901.

Hsia AY, Masliah E, McConlogue L, Yu GQ, Tatsuno G, Hu K, Kholodenko D, Malenka RC, Nicoll RA, Mucke L (1999) Plaque-independent disruption of neural circuits in Alzheimer's disease mouse models. Proc Natl Acad Sci USA 96:3228-3233.

Hsieh H, Boehm J, Sato C, Iwatsubo T, Tomita T, Sisodia S, Malinow R (2006) AMPAR removal underlies $\mathrm{A} \beta$-induced synaptic depression and dendritic spine loss. Neuron 52:831-843.

Huang J, Guh J, Chen H, Hung W, Lai Y, Chuang L (2001) Role of RAGE and the JAK/STAT-signaling pathway in AGE-induced collagen production in NRK-49F cells. J Cell Biochem 81:102-113.

Huttunen H, Fages C, Rauvala H (1999) RAGE-mediated neurite outgrowth and activation of NF- $\kappa \mathrm{B}$ require the cytoplasmic domain of the receptor but different downstream signaling pathways. J Biol Chem 274:19919-19924.

Ingelsson M, Fukumoto H, Newell KL, Growdon JH, Hedley-Whyte ET, Frosch MP, Albert MS, Hyman BT, Irizarry MC (2004) Early A $\beta$ accu- 
mulation and progressive synaptic loss, gliosis, and tangle formation in AD brain. Neurology 62:925-931.

Johnson LV, Leitner WP, Rivest AJ, Staples MK, Radeke MJ, Anderson DH (2002) The Alzheimer's A $\beta$-peptide is deposited at sites of complement activation in pathologic deposits associated with aging and age-related macular degeneration. Proc Natl Acad Sci USA 18:11830-11835.

Kelly A, Vereker E, Nolan Y, Brady M, Barry C, Loscher CE, Mills KH, Lynch MA (2003) Activation of p38 plays a pivotal role in the inhibitory effect of lipopolysaccharide and interleukin- 1 beta on long term potentiation in rat dentate gyrus. J Biol Chem 278:19453-19462.

Kislinger T, Fu C, Huber B, Qu W, Taguchi A, Yan SD, Hofmann M, Yan SF, Pischetsrider M, Stern D, Schmidt AM (1999) Ne (carboxymethyl) lysine modifications of proteins are ligands for RAGE that activate cell signaling pathways and modulate gene expression. J Biol Chem 274:31740-31749.

Kourrich S, Chapman CA (2003) NMDA receptor-dependent long-term synaptic depression in the entorhinal cortex in vitro. J Neurophysiol 89:2112-2119.

Lali FV, Hunt AE, Turner SJ, Foxwell BM (2000) The pyridinyl imidazole inhibitor SB203580 blocks phosphoinositide-dependent protein kinase activity, protein kinase B phosphorylation, and retinoblastoma hyperphosphorylation in interleukin-2-stimulated T cells independently of p38 mitogen-activated protein kinase. J Biol Chem 275:7395-7402.

Lambert MP, Barlow AK, Chromy BA, Edwards C, Freed R, Liosatos M, Morgan TE, Rozovsky I, Trommer B, Viola KL, Wals P, Zhang C, Finch CE, Krafft GA, Klein WL (1998) Diffusible, nonfibrillar ligands derived from Abeta1-42 are potent central nervous system neurotoxins. Proc Natl Acad Sci USA 95:6448-6453.

Lander H, Tauras J, Ogiste J, Moss R, Schmidt AM (1997) Activation of RAGE triggers a MAP kinase pathway regulated by oxidant stress. J Biol Chem 272:17810-17814.

Larson J, Lynch G, Games D, Seubert P (1999) Alterations in synaptic transmission and long-term potentiation in hippocampal slices from young and aged PDAPP mice. Brain Res 840:23-35.

Lesne S, Koh MT, Kotilinek L, Kayed R, Glabe CG, Yang A, Gallagher M, Ashe $\mathrm{KH}$ (2006) A specific amyloid-beta protein assembly in the brain impairs memory. Nature 440:352-357.

Li QX, Maynard C, Cappai R, McLean CA, Cherny RA, Lynch T, Culvenor JG, Trevaskis J, Tanner JE, Bailey KA, Czech C, Bush AI, Beyreuther K, Masters CL (1999) Intracellular accumulation of detergent-soluble amyloidogenic A beta fragment of Alzheimer's disease precursor protein in the hippocampus of aged transgenic mice. J Neurochem 72:2479-2487.

Lue LF, Walker DG, Brachova L, Beach TG, Rogers J, Schmidt AM, Stern DM, Yan SD (2001) Involvement of microglial receptor for advanced glycation endproducts (RAGE) in Alzheimer's disease: identification of a cellular activation mechanism. Exp Neurol 171:29-45.

Lue LF, Yan SD, Stern DM, Walker DG (2005) Preventing activation of receptor for advanced glycation endproducts in Alzheimer's disease. Curr Drug Targets CNS Neurol Disord 4:249-266.

Lustbader JW, Cirilli M, Lin C, Xu HW, Takuma K, Wang N, Caspersen C, Chen X, Pollak S, Chaney M, Trinchese F, Liu S, Gunn-Moore F, Lue LF, Walker DG, Kuppusamy P, Zewier ZL, Arancio O, Stern D, Yan SD, Wu H (2004) ABAD directly links $A \beta$ to mitochondrial toxicity in Alzheimer's disease. Science 304:448-452.

Mucke L, Masliah E, Yu GQ, Mallory M, Rockenstein EM, Tatsuno G, Hu K, Kholodenko D, Johnson-Wood K, McConlogue L (2000) High-level neuronal expression of $\mathrm{A} \beta 1-42$ in wild-type human amyloid protein precursor transgenic mice: synaptotoxicity without plaque formation. J Neurosci 20:4050-4058.

Oddo S, Caccamo A, Shepherd JD, Murphy MP, Golde TE, Kayed R, Metherate R, Mattson MP, Akbari Y, Laferla FM (2003) Triple-transgenic model of Alzheimer's disease with plaques and tangles: intracellular $\mathrm{Ab}$ and synaptic dysfunction. Neuron 39:409-421.

Ono K, Han J (2000) The p38 signal transduction pathway: activation and function. Cell Signal 12:1-13.

Parameshwaran K, Sims C, Kanju P, Vaithianathan T, Shonesy BC, Dhanasekaran M, Bahr BA, Suppiramaniam V (2007) Amyloid $\beta$-peptide $\mathrm{A} \beta(1-42)$ but not $\mathrm{A} \beta(1-40)$ attenuates synaptic AMPA receptor function. Synapse 61:367-374.

Pei JJ, Braak E, Braak H, Grundke-Iqbal I, Iqbal K, Winblad B, Cowburn RF (2001) Localization of active forms of C-jun kinase (JNK) and p38 kinase in Alzheimer's disease brains at different stages of neurofibrillary degeneration. J Alzheimers Dis 3:41-48.

Pesavento E, Capsoni S, Domenici L, Cattaneo A (2002) Acute cholinergic rescue of synaptic plasticity in the neurodegenerating cortex of anti-nerve growth factor mice. Eur J Neurosci 15:1030-1036.

Puzzo D, Vitolo O, Trinchese F, Jacob JP, Palmeri A, Arancio O (2005) Amyloid-beta peptide inhibits activation of the nitric oxide/cGMP/ cAMP-responsive element-binding protein pathway during hippocampal synaptic plasticity. J Neurosci 25:6887-6897.

Raymond CD, Ireland DR, Abraham WC (2003) NMDA receptor regulation by amyloid-b does not account for its inhibition of LTP in rat hippocampus. Brain Res 968:263-272.

Sakaguchi T, Yan SF, Yan SD, Belov D, Rong LL, Sousa M, Andrassy M, Marso SP, Duda S, Arnold B, Liliensiek B, Nawroth PP, Stern DM, Schmidt AM, Naka Y (2003) Central role of RAGE-dependent neointimal expansion in arterial restenosis. J Clin Invest Apr 111:959-972.

Sasahara M, Fries JWU, Raines EW, Gown AM, Westrum LE, Frosch MP, Bonthron DT, Ross R, Collins T (1991) PDGF B-chain in neurons of the central nervous system, posterior pituitary, and in a transgenic model. Cell 64:217-227.

Schmidt AM, Yan SD, Yan SF, Stern DM (2001) The multiligand receptor RAGE as a progression factor amplifying immune and inflammatory responses. J Clin Invest 108:949-955.

Selkoe DJ (2002) Alzheimer's disease is a synaptic failure. Science 298:789-791.

Shemer I, Holmgren C, Min R, Fulop L, Zilberter M, Sousa KM, Farkas T, Hartig W, Penke B, Burnashev N, Tanila H, Zilberter Y, Harkany T (2006) Non-fibrillar beta-amyloid abates spike-timing-dependent synaptic potentiation at excitatory synapses in layer $2 / 3$ of the neocortex by targeting postsynaptic AMPA receptors. Eur J Neurosci 23:2035-2047.

Simmons LK, May PC, Tomaselli KJ, Rydel RE, Fuson KS, Brigham EF, Wright S, Lieberburg I, Becker GW, Brems DN (1994) Secondary structure of amyloid beta peptide correlates with neurotoxic activity in vitro. Mol Pharmacol 45:373-379.

Snyder EM, Nong Y, Almeida CG, Paul S, Moran T, Choi EY, Nairn AC, Salter MW, Lombroso PJ, Gouras GK, Greengard P (2005) Regulation of NMDA receptor trafficking by amyloid-beta. Nat Neurosci 8:1051-1058.

Suzuki WA, Amaral DG (2004) Functional neuroanatomy of the medial temporal lobe memory system. Cortex 40:220-222.

Takuma K, Yao J, Huang J, Xu H, Chen X, Luddy J, Trillat AC, Stern DM, Arancio O, Yan SD (2005) ABAD enhances A $\beta$-induced cell stress via mitochondrial dysfunction. FASEB J 19:597-598.

Trinchese F, Liu S, Battaglia F, Walter S, Mathews PM, Arancio O (2004) Progressive age-related development of Alzheimer-like pathology in APP/ PS1 mice. Ann Neurol 55:801-814.

Troy CM, Rabacchi SA, Xu Z, Maroney AC, Connors TJ, Shelanski ML, Greene LA (2001) beta-Amyloid-induced neuronal apoptosis requires c-Jun N-terminal kinase activation. J Neurochem 77:157-164.

Tyszkiewicz JP, Yan Z (2005) Beta-Amyloid peptides impair PKCdependent functions of metabotropic glutamate receptors in prefrontal cortical neurons. J Neurophysiol 93:3102-3111.

Vitolo OV, Sant'Angelo A, Costanzo V, Battaglia F, Arancio O, Shelanski M (2002) Amyloid beta-peptide inhibition of the PKA/CREB pathway and long-term potentiation: reversibility by drugs that enhance cAMP signaling. Proc Natl Acad Sci USA 99:13217-13221.

Walsh DM, Klyubin I, Fadeeva JV, Cullen WK, Anwyl R, Wolfe MS, Rowan MJ, Selkoe DJ (2002) Naturally secreted oligomers of amyloid beta protein potently inhibit hippocampal long-term potentiation in vivo. Nature 416:535-539.

Walsh DM, Townsend M, Podlisny MB, Shankar GM, Fadeeva JV, El Agnaf O, Hartley DM, Selkoe DJ (2005) Certain inhibitors of synthetic amyloid beta-peptide $(A \beta)$ fibrillogenesis block oligomerization of natural Abeta and thereby rescue long-term potentiation. J Neurosci 25:2455-2462.

Wang HW, Pasternak JF, Kuo H, Ristic H, Lambert MP, Chromy B, Viola KL, Klein WL, Stine WB, Krafft GA, Trommer BL (2002) Soluble oligomers of beta amyloid (1-42) inhibit long-term potentiation but not long-term depression in rat dentate gyrus. Brain Res 924:133-140.

Wang JY, Shum A, Ho YJ, Wang JY (2003) Oxidative neurotoxicity in rat cerebral cortex neurons: synergistic effects of $\mathrm{H}_{2} \mathrm{O}_{2}$ and $\mathrm{NO}$ on apoptosis involving activation of p38 mitogen-activated protein kinase and caspase-3. J Neurosci Res 72:508-519. 
Wang Q, Walsh DM, Rowan MJ, Selkoe DJ, Anwyl R (2004) Block of longterm potentiation by naturally secreted and synthetic amyloid betapeptide in hippocampal slices is mediated via activation of the kinases c-Jun N-terminal kinase, cyclin-dependent kinase 5, and p38 mitogenactivated protein kinase as well as metabotropic glutamate receptor type 5. J Neurosci 24:3370-3378.

Wendt TM, Tanji N, Guo J, Kislinger TR, Qu W, Lu Y, Bucciarelli LG, Rong LL, Moser B, Markowitz GS, Stein G, Bierhaus A, Liliensiek B, Arnold B, Nawroth PP, Stern DM, D’Agati VD, Schmidt AM (2003) RAGE drives the development of glomerulosclerosis and implicates podocyte activation in the pathogenesis of diabetic nephropathy. Am J Pathol 162:1123-1137.

Whitlock JR, Heynen AJ, Shuler MG, Bear MF (2006) Learning induces long-term potentiation in the hippocampus. Science 313:1093-1097.

Wirths O, Multhaup G, Czech C, Blanchard V, Moussaoui S, Tremp G, Pradier L, Beyreuther K, Bayer TA (2001) Intraneuronal Abeta accumulation precedes plaque formation in beta-amyloid precursor protein and presenilin-1 double-transgenic mice. Neurosci Lett 306:116-120.

Witter MP, Groenewegen HJ, Lopes da Silva FH, Lohman AH (1989) Functional organization of the extrinsic and intrinsic circuitry of the parahippocampal region. Prog Neurobiol 33:161-253.

Yan SD, Yan SF, Chen X, Fu J, Chen M, Kuppusamy P, Smith MA, Perry G, Godman GC, Nawroth P, Zweier J, Stern DM (1995) Nonenzymatically glycated tau in Alzheimer's disease induces neuronal oxi- dant stress resulting in cytokine gene expression and release of amyloid beta-peptide. Nat Med 1:693-699.

Yan SD, Chen X, Fu J, Chen M, Zhu H, Roher A, Slattery T, Zhao L, Nagashima M, Morser J, Migheli A, Nawroth P, Stern D, Schmidt AM (1996) RAGE and amyloid-beta peptide neurotoxicity in Alzheimer's disease. Nature 382:685-691.

Yan SD, Stern D, Kane MD, Kuo YM, Lampert HC, Roher AE (1998) RAGE-Abeta interactions in the pathophysiology of Alzheimer's disease. Restor Neurol Neurosci 12:167-173.

Yan Y, Liu Y, Sorci M, Belfort G, Lustbader JW, Yan SD, Wang C (2007) Surface plasmon resonance and nuclear magnetic resonance studies of ABAD-A $\beta$ interaction. Biochemistry 46:1724-1731.

Yun SH, Huh K, Jung MW (2000) Selective enhancement of non-NMDA receptor-mediated responses following induction of long-term potentiation in entorhinal cortex. Synapse 35:1-7.

Yun SH, Jung IM, Jung MW (2002) Variation in effective stimulus pattern for induction of long-term potentiation across different layers of rat entorhinal cortex. J Neurosci 22:RC214.

Zhao D, Watson JB, Xie CW (2004) Amyloid beta prevents activation of calcium/calmodulin-dependent protein kinase II and AMPA receptor phosphorylation during hippocampal long-term potentiation. J Neurophysiol 92:2853-2858.

Zhu X, Mei M, Lee HG, Wang Y, Han J, Perry G, Smith (2005) MAP38 activation mediates amyloid-beta cytotoxicity. Neurochem Res 30:791796. 